\title{
Occurrence of Hawksbill Turtles, Eretmochelys imbricata (Reptilia: Cheloniidae), near the Baja California Peninsula, México ${ }^{1}$
}

\author{
Feffrey A. Seminoff, ${ }^{2}$ Wallace $\mathcal{F}$. Nicbols, ${ }^{3,4}$ Antonio Resendiz, ${ }^{5}$ and Louise Brooks ${ }^{3,6}$
}

\begin{abstract}
From 1997 to 2001 the occurrence of hawksbill turtles (Eretmochelys imbricata) was characterized at neritic foraging habitats along the Pacific coast of the Baja California Peninsula and in the Gulf of California, México, through inwater capture of live turtles and searches for dead carcasses. We recorded a total of 27 hawksbill turtles: 14 (four live-captured and 10 strandings [dead turtles]) along the Pacific coast of Baja California and 13 (seven live-captured and six strandings) in the Gulf of California. The range of straight carapace lengths for hawksbill turtles from the Pacific and the Gulf of California was 35.4 to $52.5 \mathrm{~cm}$ $($ mean $=42.5 \mathrm{~cm}$ ) and 34.4 to $74.2 \mathrm{~cm}$ (mean $=48.0 \mathrm{~cm})$, respectively. Although hawksbills are uncommon in coastal neritic habitats near Baja California, their continued presence indicates that this region should be included as a focus area for future conservation efforts.
\end{abstract}

The hawksBill tURTle, Eretmochelys imbricata (Linnaeus, 1766), is a highly endangered and inadequately understood marine turtle with circumtropical distribution (Witzell 1983). The species is best described by its elongated beak and imbricate scutes on the carapace and plastron, especially during juvenile and subadult life stages. Known as "tortoiseshell" or "bekko," these plates have caused the hawksbill turtle to be the target

1 This research was supported by Wallace Research Foundation, Earthwatch Institute, David and Lucile Packard Foundation, and the Center for Coastal Studies (SFS). Manuscript accepted 12 March 2002.

2 Archie Carr Center for Sea Turtle Research and Department of Zoology, University of Florida, P.O. Box 118525, Gainesville, Florida 32611 (E-mail: seminoff@ zoology.ufl.edu).

3 Wildcoast Conservation Team, P.O. Box 324, Davenport, California 95017.

${ }^{4}$ Department of Herpetology, California Academy of Sciences, Golden Gate Park, San Francisco, California 94118.

${ }_{5}$ Centro Regional de Investigación Pesquera, El Sausal de Rodríguez, Ensenada, Baja California, México.

${ }^{6}$ Moss Landing Marine Laboratories, Moss Landing, California 95039.

Pacific Science (2003), vol. 57, no. 1:9-16

(C) 2003 by University of Hawai'i Press

All rights reserved of an exhaustive harvest for artisanal uses throughout the world (Groombridge and Luxmoore 1989). This demand, coupled with the harvest of eggs, juveniles, and adults for food, has caused hawksbill turtle populations to plummet worldwide (Meylan and Donnelly 1999).

Like most sea turtles, hawksbill turtles are migratory and use a wide range of broadly separated localities and habitats during their lifetime. It has been hypothesized that upon leaving the nesting beach hatchlings begin an oceanic phase, perhaps floating passively in major current systems (gyres) for several years (Carr 1987). These turtles are then thought to recruit from oceanic habitats to neritic developmental habitats where they forage and grow until maturity (Witzell 1983). Upon attaining sexual maturity hawksbill turtles commence breeding migrations between foraging grounds and nesting areas that are undertaken every few years (Witzell 1983). Migrations are carried out by males and females and may traverse oceanic zones, sometimes spanning thousands of kilometers (Meylan 1999) and sometimes only a few hundred kilometers or less (Ellis at al. 2000, Mortimer and Balazs 2000, Horrocks et al. 2001). During nonbreeding periods adults reside at coastal neritic feeding areas that may coincide with juvenile developmental habitats (e.g., Grant et al. 1997). 
In the eastern Pacific Ocean, hawksbill turtles were once common in neritic habitats from México to Ecuador (Cliffton et al. 1982). Spanish missionaries reported that the species was common along the Pacific and Gulf coasts of Baja California during the late 1700s (Aschmann 1966). Indigenous Seri elders explain that large hawksbill turtles were abundant as recently as the $1950 \mathrm{~s}$ (Felger and Moser 1985), but due to intense commercial harvest this species became rare to absent in most localities in the eastern $\mathrm{Pa}$ cific Ocean by the late 1960s (Caldwell 1962, Cliffton et al. 1982). Despite these reports, accounts of nesting activity have been scant. Cornelius (1982) reported infrequent nesting along the Pacific coast of Central America. In México, a large population was reported from the Tres Marías Islands, which may have been a major breeding ground (Parsons 1962). By the 1980s, however, no major hawksbill turtle nesting beaches remained in the eastern Pacific Ocean (Cliffton et al. 1982).

Hawksbill turtles currently are listed as critically endangered in the World Conservation Union (IUCN) Red Data Book (Hilton-Taylor 2000) and are included in Appendix 1 of the Convention on International Trade in Endangered Species of Wild Fauna and Flora (CITES). This endangered status has prompted calls for increased research and protection (National Marine Fisheries Service and U.S. Fish and Wildlife Service 1998); however, the development of appropriate management strategies has been hindered by a lack of empirical information on the demography of hawksbills, particularly in the Pacific Ocean. Moreover, in the most recent status justification for hawksbill turtles, Meylan and Donnelly (1999) indicated that the paucity of data for hawksbill turtles in the eastern Pacific Ocean precluded up-todate population assessments for this region. Clearly, additional data are needed to characterize hawksbill turtle populations in the eastern Pacific. In this paper, we describe the occurrence of hawksbill turtles in coastal waters of the Baja California Peninsula, México.

\section{MATERIALS AND METHODS}

Between 1997 and 2001 we studied hawksbill turtles along the Pacific coast of the Baja California Peninsula and in the Gulf of California, México (Figure 1). Study sites along the Pacific coast $\left(24^{\circ} 15^{\prime}-27^{\circ} 48^{\prime} \mathrm{N}\right.$ and $111^{\circ}$ $\left.30^{\prime}-114^{\circ} 08^{\prime} \mathrm{W}\right)$ were located in Laguna Ojo de Liebre, Laguna San Ignacio, and Bahía Magdalena; study sites within the Gulf of California $\left(22^{\circ} 52^{\prime}-28^{\circ} 58^{\prime} \mathrm{N}\right.$ and $109^{\circ} 54^{\prime}-113^{\circ} 33^{\prime} \mathrm{W}$ ) included Bahía de los Angeles, Infiernillo Channel, Loreto, and Cabo Pulmo. These areas are neritic feeding grounds for green turtles (Cbelonia mydas), and the large abundance of invertebrate fauna (Brusca 1980) suggests that they are potential foraging areas for hawksbill turtles. Efforts to document hawksbill turtle presence in these areas included (1) in-water capture of live turtles, (2) beach stranding surveys

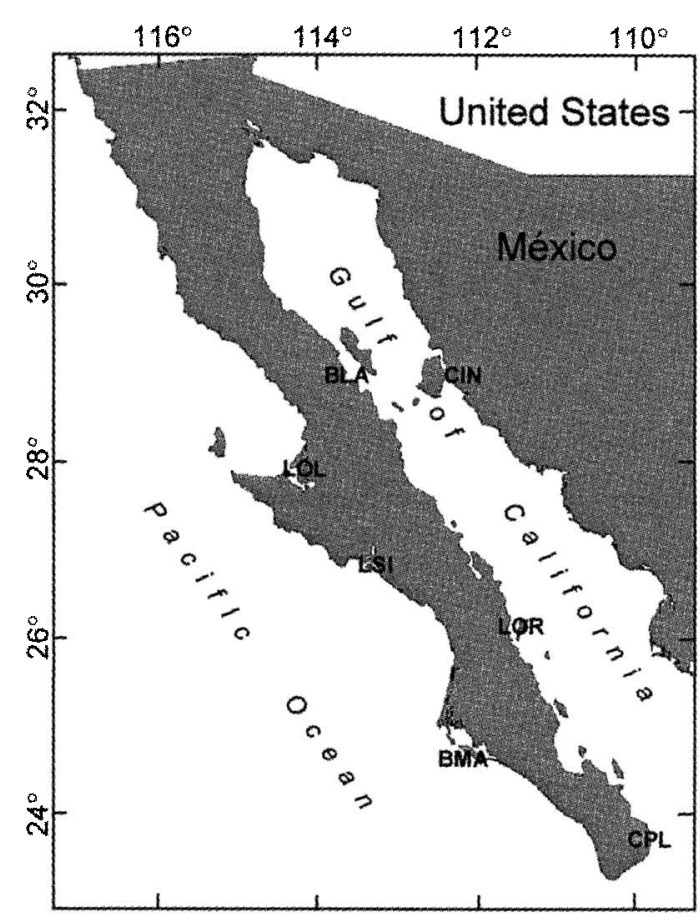

Figure 1. Map of the Baja California Peninsula with study areas identified: LOL, Laguna Ojo de Liebre; LSI, Laguna San Ignacio; BMA, Bahía Magdalena; CPL, Cabo Pulmo; LOR, Loreto; BLA, Bahía de los Angeles; CIN, Infiernillo Channel. 
for dead carcasses, and (3) documentation of turtle consumption in human coastal communities.

Hawksbill turtles were captured with entanglement nets ( 100 by $8 \mathrm{~m}$; mesh size, $50 \mathrm{~cm}$ stretched) placed along the shallow perimeter of each study area. Distance from shore and water depth of netting sites ranged from 50 to $750 \mathrm{~m}$, and 2 to $27 \mathrm{~m}$, respectively. Nets were set during both day and night and monitored regularly. Turtles were removed immediately upon capture and held captive up to $24 \mathrm{hr}$. For each turtle, we recorded straight-line carapace length $(\mathrm{SCL})( \pm 0.1 \mathrm{~cm})$ from the nuchal notch to the posteriormost portion of the rear marginals using a forester's caliper. Before release each turtle was double tagged with Inconel tags (style 681, National Band and Tag Company, Newport, Kentucky): one tag in the first large proximal scale of each front flipper (Balazs 1999).

To quantify the occurrence of hawksbill strandings (i.e., dead turtles) we conducted beach surveys along coastal perimeters of each study area. Along the Pacific coast, surveys were quarterly (occurring in January, April, July, and October); in the Gulf of California surveys were performed monthly, from May to September. In addition, we carried out sporadic searches of fish camps and refuse dumps near each study site. Data were recorded on each sea turtle carcass found following Gardner and Nichols (2001). Measurements followed the same procedure as that for live-captured turtles. We described presence of external abnormalities, carried out necropsies when possible (Work 2000), and recorded cause of death when known. After each carcass was examined, it was marked with neon spray paint or collected to avoid duplicate counting.

We used a one-way analysis of variance (ANOVA) to determine if the mean SCL of hawksbill turtles differed between the Pacific coast and the Gulf of California.

\section{RESULTS}

We recorded a total of 27 hawksbill turtles during this study: 14 (four live-captured and
10 strandings) along the Pacific coast of Baja California and 13 (seven live-captured and six strandings) in the Gulf of California (Table 1). Mean SCL of hawksbill turtles examined in the Pacific and Gulf of California were $42.5 \mathrm{~cm} \quad(\mathrm{SE}=1.5 ;$ range $=35.4-52.5 \mathrm{~cm})$ and $48.0 \mathrm{~cm}(\mathrm{SE}=3.4$; range $=34.4-74.2$ $\mathrm{cm})$, respectively. There was no difference in the mean SCL of these groups (ANOVA, $F=1.46 ; \mathrm{df}=1,25 ; P=0.15)$. The greatest number of hawksbill turtles at the Pacific sites was in the $40-$ to $45-\mathrm{cm}$ SCL size range $(n=6)$. At the Gulf of California sites a maximum of four turtles were in both the 35to $40-\mathrm{cm} \mathrm{SCL}$ and $45-$ to $50-\mathrm{cm}$ SCL size ranges. A summary of the number of turtles per $5-\mathrm{cm}$ size class for each disposition in each region is presented in Figure 2.

Of the 16 hawksbill turtles found dead during this study, 14 turtles were encountered during stranding surveys, one fresh carcass was recovered from a dump site, and one turtle, for which no size datum is available, was seen eaten in the local community. Among turtles encountered during stranding surveys, mortality was suspected to be due to incidental capture in local fisheries: gill nets are commonly utilized in the region for harvest of a variety of finfish species (Gardner and Nichols 2001). We saw no evidence of contact with oil or tar, no turtles had boat collision or propeller damage, and necropsies of stranded carcasses revealed no anomalous features indicative of natural death. Moreover, two hawksbill turtles from the Gulf of California had stomachs filled with sponge fragments (Haliclona spp. [J.A.S., unpubl. data]), suggesting that these individuals were actively foraging before death. On three occasions in the Gulf of California we encountered stranded turtles with missing carapace scute plates, suggesting that the animals were exploited for tortoiseshell. Whether these were opportunistically harvested or actively hunted is unknown. We do not know the cause of death for the single hawksbill encountered at the dump site; however, the fact that this clean carapace had meat removed and was actively discarded indicates that human consumption was likely. 
TABLE 1

Summary of Eretmochelys imbricata Specimens Recorded from Coastal Waters near the Baja California Peninsula from 1997 to 2001

\begin{tabular}{|c|c|c|c|c|}
\hline Locality & Date & $\begin{array}{l}\text { Size (SCL) } \\
(\mathrm{cm})\end{array}$ & Location $^{a}$ & Disposition $^{b}$ \\
\hline \multicolumn{5}{|l|}{ Pacific } \\
\hline & 5 June 1998 & 40.3 & $\mathrm{BMA}$ & A \\
\hline & 5 June 1998 & 36.6 & $\mathrm{BMA}$ & A \\
\hline & 5 June 1998 & 43.3 & $\mathrm{BMA}$ & A \\
\hline & 15 Apr. 1999 & 47.3 & BMA & D \\
\hline & 1 May 1999 & 35.4 & $\mathrm{BMA}$ & $\mathrm{D}$ \\
\hline & 17 June 1999 & 44.5 & BMA & D \\
\hline & 22 June 1999 & 52.2 & BMA & $\mathrm{C}$ \\
\hline & 14 Aug. 1999 & 41.2 & $\mathrm{BMA}$ & $\mathrm{D}$ \\
\hline & 30 Oct. 2000 & 37.0 & $\mathrm{BMA}$ & $\mathrm{D}$ \\
\hline & 9 July 2001 & 52.4 & $\mathrm{BMA}$ & $\mathrm{A}$ \\
\hline & 20 July 2001 & 42.0 & $\mathrm{BMA}$ & $\mathrm{D}$ \\
\hline & 20 July 2001 & 39.5 & $\mathrm{BMA}$ & $\mathrm{D}$ \\
\hline & 20 July 2001 & 41.5 & $\mathrm{BMA}$ & $\mathrm{D}$ \\
\hline & 4 Apr. 2001 & $\mathrm{NA}$ & $\mathrm{BMA}$ & $\mathrm{D}$ \\
\hline \multicolumn{5}{|c|}{ Gulf of California } \\
\hline & $\begin{array}{l}1 \text { Aug. } 1997 \\
9 \text { Oct. } 1997\end{array}$ & $\begin{array}{l}56.4 \\
52.2\end{array}$ & $\begin{array}{l}\text { CPL } \\
\text { BLA }\end{array}$ & $\begin{array}{l}\mathrm{D} \\
\mathrm{A}\end{array}$ \\
\hline & 8 Jan. 1998 & 36.4 & BLA & A \\
\hline & 23 Jan. 1998 & 34.4 & BLA & A \\
\hline & 20 Sept. 1998 & 38.0 & BLA & A \\
\hline & 8 Jan. 1999 & 37.6 & BLA & A \\
\hline & 9 Sept. 1999 & 35.9 & BLA & $\mathrm{A}$ \\
\hline & 23 May 1999 & 64.5 & CIN & $\mathrm{D}$ \\
\hline & 1 July 1999 & 45.0 & $\mathrm{CIN}$ & $\mathrm{D}$ \\
\hline & 20 Jan. 2000 & 74.2 & BLA & A \\
\hline & 2 June 2000 & 45.1 & $\mathrm{CIN}$ & $\mathrm{D}$ \\
\hline & 2 June 2000 & 48.0 & CIN & $\mathrm{D}$ \\
\hline & 12 Mar. 2001 & 42.5 & $\mathrm{CIN}$ & $\mathrm{D}$ \\
\hline
\end{tabular}

a See Figure 1 for location codes.

${ }^{b} \mathrm{~A}$, alive; $\mathrm{D}$, dead; $\mathrm{C}$, consumed.

Overall, the four live-captured hawksbills from the Pacific coast and the seven live hawksbills from the Gulf of California represent $3.1 \%$ and $2.9 \%$, respectively, of all livecaptured sea turtles (including Cbelonia mydas, Caretta caretta, and Lepidocbelys olivacea) in each region over the same time period (Seminoff 2000, Nichols 2002). Of the stranded hawksbill turtles, the 10 dead individuals from the Pacific coast and the six dead individuals from the Gulf of California represent $0.8 \%$ and $6.3 \%$ of all strandings in the respective regions (Gardner and Nichols 2001, Nichols 2002; J.A.S., unpubl. data).

\section{DISCUSSION}

The demographical data described here are the first substantial information on hawksbill turtles in the eastern Pacific Ocean in over two decades (see Cliffton et al. 1982). Sustained reductions of hawksbills in this region may hinder future research on demography; nonetheless, we encourage additional studies to further characterize the current hawksbill population in the eastern Pacific Ocean.

Considering that most sea turtles attain maturity at or near mean nesting size (Chaloupka and Limpus 1997), the size range in 

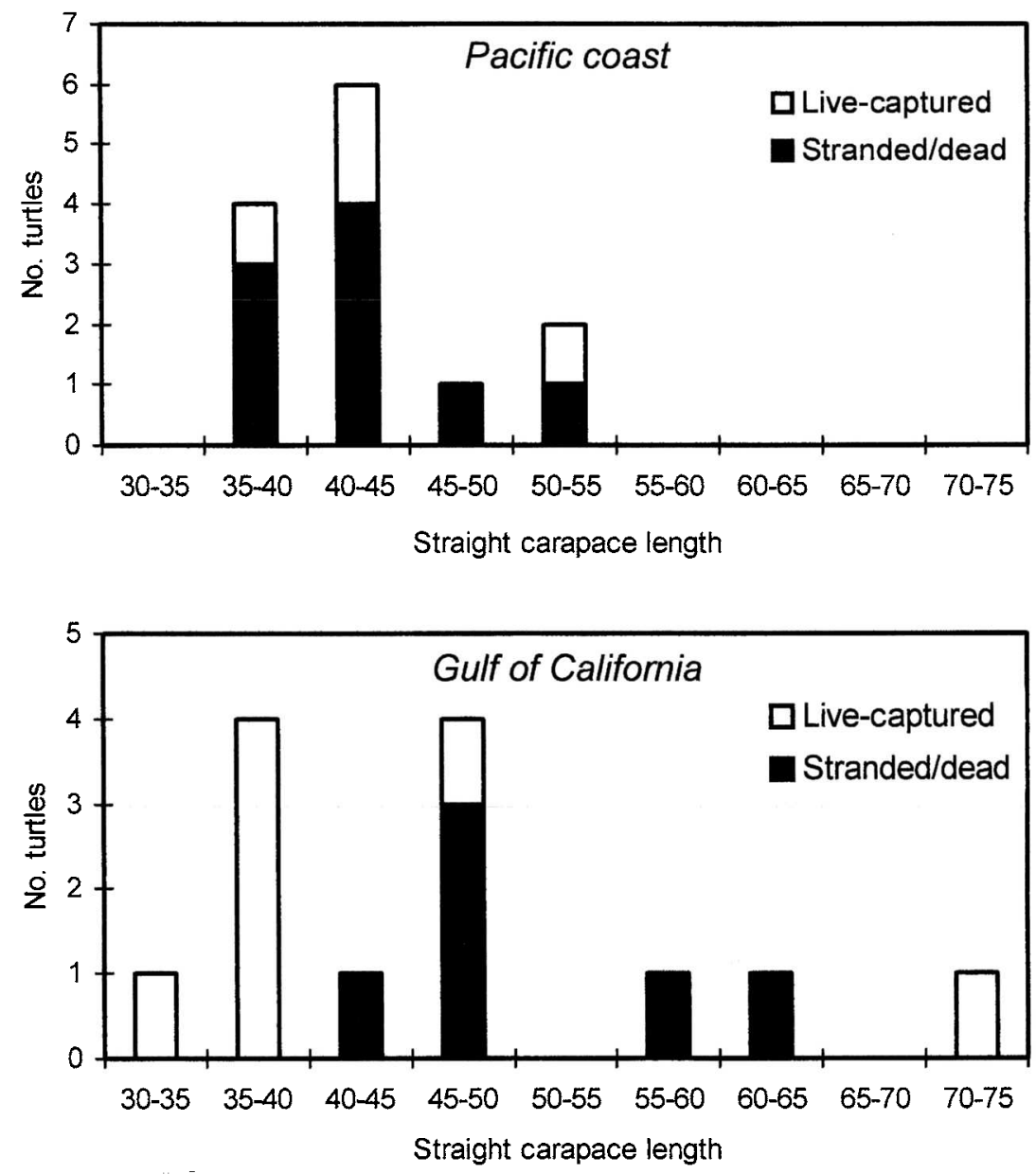

Figure 2. Summary of size class and disposition for hawksbill turtles (Eretmocbelys imbricata) captured near the Baja California Peninsula, México.

this study (34.4 to $74.2 \mathrm{~cm}$ SCL) is indicative of a population consisting primarily of juveniles and subadults. All but one turtle encountered during this study were substantially smaller than the mean nesting size in American Samoa (68.6 cm SCL), one of the nearest hawksbill nesting beaches for which size data are available (Witzell and Banner 1980). The preponderance of juveniles and subadults may be due to some developmental shift in habitat preference as hawksbill turtles attain sexual maturity. Although there are few data regarding this, evidence for such a shift can be inferred by the fact that adults are similarly sparse from other hawksbill populations
(Hirth et al. 1992, Sanches and Bellini 1999).

Hawksbills near Baja California apparently shift from the epipelagic juvenile phase to the neritic juvenile phase at a size consistent with that of populations in other regions of the Pacific Ocean. While the smallest hawksbill turtle encountered during this study measured $34.4 \mathrm{~cm}$ SCL, Limpus (1992) reported settlement sizes starting at $32.5 \mathrm{~cm}$ curved carapace length (CCL) for hawksbills in the southern Great Barrier Reef of Australia, and Hirth et al. (1992) reported that hawksbills in Papua New Guinea begin to settle at $31.8 \mathrm{~cm}$ SCL. In contrast, hawksbills in the Caribbean leave the oceanic zone and begin foraging in 
neritic habitats at substantially smaller size (20 to $25 \mathrm{~cm}$ SCL: Meylan 1988, Leon and Diez 1999).

Although nesting data are scant for hawksbills in the eastern Pacific, the presence of hawksbills in neritic habitats of Baja California and the Gulf of California suggests that this species continues to nest in proximity to these areas. The stock structure and nesting beach to feeding area links for hawksbill turtles in the eastern Pacific Ocean are, however, not known. The closest concentrated nesting area for the hawksbill turtle is located in Hawai'i (Balazs 1982, Katahira et al. 1994). To enter the eastern Pacific Ocean, posthatchlings dispersing from nesting beaches at that Central Pacific locality could use the easterly flowing North Pacific Current and end up in the eastern Pacific (Lagerloef et al. 1999). Juveniles moving along this trajectory would, however, cross a pelagic zone of more than $5000 \mathrm{~km}$ throughout which hawksbill turtle presence is rare to nonexistent, thus indicating that origins in the Central Pacific Ocean are unlikely. Of 2534 turtle sightings during recent surface faunal transects in the eastern tropical Pacific Ocean, not a single $E$. imbricata was registered in the pelagic zone (Olson et al. 2000, 2001).

Hawksbill turtles continue to nest, albeit rarely, along the Pacific coast of México. Accounts of sporadic nesting in the Mexican coastal states of Jalisco and Nayarit indicate potential nesting beach origins within 1000 $\mathrm{km}$ of the habitats surveyed during this study (Chavez 1989; R. Briseño, pers. comm.). The Tres Marías Islands in Pacific México, located ca. $600 \mathrm{~km}$ from the southern tip of the Baja California Peninsula, may also continue to have hawksbill turtle nesting activity (Márquez 1990). Shorter travel distances from these Pacific nesting sites relative to distances from Central Pacific sites suggest that they may be more likely points of origin for hawksbill turtles occurring near Baja California. Clearly, genetic data are needed from nesting and foraging areas to elucidate the hawksbill turtle stock structure in the eastern Pacific Ocean. The use of satellite telemetry on nesting females may also elucidate the nesting beach to foraging area link for hawksbill turtles in the eastern Pacific Ocean, such as has been conducted in the Hawaiian Islands (Ellis et al. 2000).

Despite the decade that has passed since the presidential decree aimed at protecting sea turtles in México (Anonymous 1990), the hawksbill turtle population in Pacific México remains critically low. The presence of butchered and stranded turtles encountered during this study indicates that hawksbills continue to be adversely impacted by humans in the Baja California region. Efforts to prevent such mortality will rely, in part, on a better understanding of hawksbill presence in this region. This underscores the need for additional biological information that will guide the focus and implementation of future recovery efforts. Although it may be many years before the turtles observed during this study attain sexual maturity, survivorship of juveniles has a substantial effect on sea turtle population growth (Crouse et al. 1987). Thus, despite the low number of hawksbill turtles in Baja California waters, this region should be considered as a priority area for recovery efforts in the eastern Pacific.

\section{ACKNOWLEDGMENTS}

We are indebted to S. Gardner, J. Gilmore, A. Hernandez, G. Hoeffer, J. Lopez, L. Monti, G. Nabhan, R. Rangel, B. Resendiz, H. Romero, O. Savin, T. Smith, L. Yarnell, and the Earthwatch team members for assistance with field activities. We thank $\mathrm{K}$. Moran, G. Balazs, and one anonymous reviewer for helpful comments that improved early versions of the manuscript. Turtle capture was authorized by Secretaria del Medio Ambiente, Recursos Naturales, y Pesca, México (permit nos. 150496-213-03, 280597213-03, 190698-213-03, and 280499-213-03). All turtle handling was in full compliance with University of Florida IACUC protocol.

\section{Literature Cited}

Anonymous. 1990. Acuerdo por el que se establece veda para las especies y subespecies de tortuga marina en aguas de jurisdicción Federal del Golfo de México y Mar Cari- 
be, así como en las costas del Océano Pacífico, incluyendo el Golfo de California. Diario Official de la Federacion. Federal District, México, 28 May 1990.

Aschmann, H. 1966. The natural and human history of Baja California-from manuscripts by Jesuit missionaries in the decade 1752-1762. Publication No. 7. Dawson's Book Shop, Los Angeles, California.

Balazs, G. H. 1982. Status of sea turtles in the central Pacific. Pages 243-252 in K. A. Bjorndal, ed. Biology and conservation of sea turtles. Smithsonian Institution Press, Washington, D.C.

-1999. Factors to consider in the tagging of sea turtles. Pages 101-109 in K. L. Eckert, K. A. Bjorndal, F. A. AbreuGrobois, and M. Donnelly, eds. Research and management techniques for the conservation of sea turtles. IUCN/SSC Marine Turtle Specialist Group Publ. 4.

Brusca, R. C. 1980. Common intertidal invertebrates of the Gulf of California. University of Arizona Press, Tucson.

Caldwell, D. K. 1962. Sea turtles in Baja California waters (with special reference to those of the Gulf of California), and the description of a new subspecies of northeastern Pacific green turtle. Contrib. Sci. Los Angel. Cty. Mus. 61:1-31.

Carr, A. 1987. New perspectives on the pelagic stage of sea turtle development. Conserv. Biol. 1:103.

Chaloupka, M. Y., and C. J. Limpus. 1997. Robust statistical modeling of hawksbill turtle growth rates (southern Great Barrier Reef). Mar. Ecol. Prog. Ser. 146:1-8.

Chavez, M. 1989. Presencia de tortuga carey, Eretmochelys imbricata, en Playa Platanitos, Nayarit, México. Pages 28-29 in Memorias del VI Encuentro Interuniversitario Mexicano sobre Tortugas Marinas. Universidad Autónoma de México, 7-10 July 1989.

Cliffton, K., D. O. Cornejo, and R. S. Felger. 1982. Sea turtles of the Pacific coast of México. Pages 199-209 in K. A. Bjorndal, ed. Biology and conservation of sea turtles: Smithsonian Institution Press, Washington, D.C.

Cornelius, S. E. 1982. Status of sea turtles along the Pacific coast of Middle America. Pages 211-219 in K. A. Bjorndal, ed. Biology and conservation of sea turtles. Smithsonian Institution Press, Washington, D.C.

Crouse, D. T., L. B. Crowder, and H. Caswell. 1987. A stage-based model for loggerhead sea turtles and implications for conservation. Ecology 68:1412-1423.

Ellis, D. M., G. H. Balazs, G. Gilmartin, S. K. K. Murakawa, and L. K. Katahira. 2000. Short-range reproductive migrations of hawksbill turtles in the Hawaiian Islands as determined by satellite telemetry. Pages 252-253 in F. A. Abreu-Grobois, R. Briseño-Dueñas, R. Márquez-Millán, and L. Sarti-Martínez, comps. Proceedings of the 18th International Sea Turtle Symposium. NOAA Tech. Memo. NMFSSEFSC-443.

Felger, R. S., and M. B. Moser. 1985. People of the desert and sea: Ethnobotany of the Seri Indians. University of Arizona Press, Tucson.

Gardner, S. C., and W. J. Nichols. 2001. Assessment of sea turtle mortality rates in the Bahía Magdalena region, Baja California Sur, México. Chelonian Conserv. Biol. 4:197-199.

Grant, G. S., P. Craig, and G. H. Balazs. 1997. Notes on juvenile hawksbill and green turtles in American Samoa. Pac. Sci. $51: 48-53$.

Groombridge, B., and R. Luxmoore. 1989. The green turtle and hawksbill (Reptilia: Cheloniidae): World status, exploitation, and trade. CITES Secretariat, Lausanne, Switzerland.

Hilton-Taylor, C. 2000. IUCN Red list of threatened species. IUCN, Gland, Switzerland and Cambridge, U.K.

Hirth, H. F., M. Huber, T. Frohm, and T. Mala. 1992. A natural assemblage of immature green (Chelonia mydas) and hawksbill (Eretmochelys imbricata) turtles on the fringing reef of Wurulu Island, Papua New Guinea. Micronesica 25:145-153.

Horrocks, J. A., L. A. Vermeer, B. Krueger, M. Coyne, B. A. Schroeder, and G. H. Balazs. 2001. Migration routes and destination characteristics of post-nesting 
hawksbill turtles satellite-tracked from Barbados, West Indies. Chelonian Conserv. Biol. 4:107-114.

Katahira, L. K., C. M. Forbes, A. H. Kikuta, G. H. Balazs, and M. Bingham. 1994. Recent findings and management of hawksbill turtle nesting beaches in Hawaii. Page 69 in K. A. Bjorndal, A. B. Bolten, D. A. Johnson, and P. J. Eliazar, comps. Proceedings of the 14th Annual Symposium on Sea Turtle Biology and Conservation. NOAA Tech. Memo. NMFS-SEFSC-351. Lagerloef, G. S. E., G. T. Mitchum, R. B. Lukas, and P. P. Niiler. 1999. Tropical Pacific surface currents estimated from altimeter, wind, and drifter data. J. Geophys. Resourc. 104 (10C): 313-326.

Leon, Y. M., and C. E. Diez. 1999. Population structure of hawksbill turtles on a foraging ground in the Dominican Republic. Chelonian Conserv. Biol. 3:230236.

Limpus, C. J. 1992. The hawksbill turtle, Eretmochelys imbricata, in Queensland: Population structure within a southern Great Barrier Reef feeding ground. Wildl. Res. 19:489-506.

Linnaeus, C. 1766. Systema naturae. Vol. 1. Stockholm.

Márquez, R. 1990. FAO species catalog: Sea turtles of the world. FAO Fish. Synop. 125.

Meylan, A. B. 1988. Spongivory in hawksbill turtles: A diet of glass. Science (Washington, D.C.) 239:393.

- - 1999. International movements of immature and adult hawksbill turtles (Eretmocbelys imbricata) in the Caribbean Region. Chelonian Conserv. Biol. 3:189194.

Meylan, A. B., and M. Donnelly. 1999. Status justification for listing the hawksbill turtle (Eretmochelys imbricata) as critically endangered on the 1996 IUCN Red list of threatened animals. Chelonian Conserv. Biol. 3:200-224.

Mortimer, J. A., and G. H. Balazs. 2000. Post-nesting migrations of hawksbill turtles in the granitic Seychelles and implications for conservation. Pages 22-26 in $\mathrm{H}$. Kalb and T. Wibbels, comps. Proceedings of the 19th Annual Symposium on Sea Turtle Biology and Conservation. NOAA Tech. Memo. NMFS-SEFSC-443.

National Marine Fisheries Service and U.S. Fish and Wildlife Service. 1998. Recovery plan for U.S. Pacific populations of the hawksbill turtle (Eretmochelys imbricata). National Marine Fisheries Service, Silver Spring, Maryland.

Nichols, W. J. 2002. Biology and conservation of the sea turtles of Baja California. $\mathrm{Ph} . \mathrm{D}$. diss., University of Arizona, Tucson.

Olson, P. A., R. L. Pitman, L. T. Ballance, and S. B. Reilly. 2000. Summary of seabird, marine turtle, and surface fauna data collected during a survey in the eastern tropical Pacific Ocean, July 30-December 9, 1998. NOAA Tech. Memo. NMFSSWFSC-298.

Olson, P. A., R. L. Pitman, L. T. Ballance, K. R. Hough, P. H. Dutton, and S. B. Reilly. 2001. Summary of seabird, marine turtle, and surface fauna data collected during a survey in the eastern tropical Pacific Ocean, July 28-December 9, 1999. NOAA Tech. Memo. NMFS-SWFSC-301.

Parsons, J. 1962. The green turtle and man. University of Florida Press, Gainesville.

Sanches, T. M., and C. Bellini. 1999. Juvenile Eretmochelys imbricata and Chelonia mydas in the Archipelago of Fernando de Noronha, Brazil. Chelonian Conserv. Biol. 3:309-311.

Seminoff, J. A. 2000. Biology of the East Pacific green turtle, Chelonia mydas agassizii, at a warm temperate feeding area in the Gulf of California, México. Ph.D. diss., University of Arizona, Tucson.

Witzell, W. 1983. Synopsis of biological data on the hawksbill turtle, Eretmochelys imbricata (Linnaeus, 1766). FAO Fish. Synop. 137.

Witzell, W. N., and A. Banner. 1980. The hawksbill turtle, Eretmochelys imbricata, in Western Samoa. Bull. Mar. Sci. 30:571579.

Work, T. W. 2000. Sea turtle necropsy manual for biologists in remote refuges. U.S. Geological Survey National Wildlife Health Center, Hawai'i Field Station. 